\title{
Coronary artery stents and surgery; the basis of sound perioperative management
}

\author{
Stephen Bolsin ${ }^{1^{*}}$, Chin Hiew ${ }^{2}$, Garth Birdsey ${ }^{3}$, Mark Colson ${ }^{4}$, Jessica Gillet ${ }^{4}$ \\ ${ }^{1}$ Department of Epidemiology \& Preventative Medicine, Monash University, Melbourne, Australia; \\ *Corresponding Author: stevebolsin@gmail.com \\ ${ }^{2}$ Department of Cardiology, The Geelong Hospital, Victoria, Australia \\ ${ }^{3}$ Geelong Hospital Pharmacy, Victoria, Australia \\ ${ }^{4}$ Department of Anaesthesia, Geelong Hospital, Victoria, Australia
}

Received 19 August 2013; revised 19 September 2013; accepted 5 October 2013

Copyright (C) 2013 Stephen Bolsin et al. This is an open access article distributed under the Creative Commons Attribution License, which permits unrestricted use, distribution, and reproduction in any medium, provided the original work is properly cited.

\begin{abstract}
The introduction of drug-eluting stents (DES) to interventional cardiology heralded a limited time of increased anaesthetic and surgical complications in patients implanted with these devices. The horns of the dilemma, in the anaesthetic and surgical management of patients in the first $3-6$ months after the $1^{\text {st }}$ generation DES insertion, were between the risk of bleeding from continued clopidogrel treatment and the risk of instent thrombosis and myocardial infarction following discontinuation of dual antiplatelet therapy, clopidogrel and aspirin. Initial accounts of early catastrophic cardiac and haemorrhagic complications, at the time of elective or emergency surgery, following DES insertion, were followed by equally worrying reports of in-stent thrombosis many months after DES insertion. Initial recommendations for the conduct of safe operations were propagated in the literature before formal guidelines were produced. This article summarises the issues identified in the development of interventional cardiology particularly DES and the requirement for ongoing antiplatelet therapy. The article reviews the treatment protocols that are still applicable for the different devices that have been deployed in clinical practice.
\end{abstract}

Keywords: Coronary Artery Stent; Thrombosis; Haemorrhage; Surgery Complication

\section{INTRODUCTION}

The development of balloon angioplasty by cardiolo- gists was followed by the introduction of bare metal stents (BMS) to relieve obstructions in the coronary arteries. After the identification of endothelial proliferation, and endothelial hyperplasia, as a cause of late in-stent thrombosis, drug-eluting stents (DES) provided interventional cardiologists with a potentially safe solution to the problem. However, the DES themselves, along with the dual antiplatelet therapy contributed to a time of increased anaesthetic and surgical complications in patients with these devices implanted [1,2]. For patients requiring surgery in the first 3 - 6 months following implantation of a $1^{\text {st }}$ generation DES, the horns of the dilemma were between the risk of bleeding from, continued clopidogrel and aspirin treatment and the risk of in-stent thrombosis and myocardial infarction following discontinuation of dual antiplatelet therapy, clopidogrel and aspirin $[3,4]$.

After accounts of early catastrophic complications from both bleeding and stent thrombosis, at the time of elective or emergency surgery, following DES insertion, there were then also worrying reports of in-stent thrombosis many months after DES insertion [5-12]. Initial recommendations for anaesthetists, perioperative physicians and surgeons relating to the safe conduct of major operations were propagated in the literature and followed by formal guidelines [13-16].

In this article we summarise the issues relevant to the developments in interventional cardiology particularly DES and the requirement for ongoing antiplatelet therapy [17]. We review the treatment protocols that are still applicable to the different devices currently in use in clinical practice and identify safe and appropriate plans for dealing with emergency and elective surgery for these patients [16,18-21]. 


\section{BALLOON ANGIOPLASTY, BARE-METAL AND DRUG-ELUTING STENT INSERTION}

Following the demonstration of improved outcomes from coronary artery stenting at the time of balloon angioplasty intimal hyperplasia contributed to a measureable incidence of re-stenosis [22]. It was postulated that inhibiting the division of endothelial cells that might attempt to colonise the new intima in the bare-metal stent could reduce restenosis rates after angioplasty and stenting. The early trials documented further improvements in reducing re-stenosis rates with the use of antimitotic drugs included in the stent covering $[23,24]$. The drugs used were sirolimus and paclitaxel, which were incorporated into the covering of the metal in the stent and designed to be slowly washed out or eluted from the covering layer $[25,26]$. These were the drug-eluting stents (DES), which rapidly became very popular with interventional cardiologists [24,27].

The DES had reduced the incidence of intimal hyperplasia and restenosis so for cardiologists all problems seemed to be solved $[24,28,29]$.

\section{ANTIPLATELET THERAPY FOR BARE-METAL STENTS AND DRUG-ELUTING STENTS}

A metal stent in the coronary circulation is at high risk of causing platelet activation and stimulating platelet thrombus formation $[24,27]$. Consequently anticoagulant precautions must be employed to prevent thrombus forming in the coronary circulation and precipitating the problem the stent is deployed to prevent, which is myocardial infarction $[22,28,30]$. The management of periprocedural anticoagulation has evolved along with the technology of the stents. Early bare-metal stents (BMS) were protected with heparin, but the success of the PRISM study confirmed the use of glycoprotein IIb/IIIa inhibitors with heparin as potent prophylaxis against thrombus formation in the presence of high-risk lesions in the coronary circulation [31-34]. With the introduction of long-acting oral P2Y12 receptor blockers the problem of preventing in-stent thrombosis appeared to be solved $[8,35,36]$. However the question that remained unanswered was "How long do patients need to remain on antiplatelet therapy following DES deployment". The answer was partly provided by the January $4^{\text {th }}$ update from the US Food and Drug Administration, which recommended a longer duration of antiplatelet therapy for both paclitaxel and sirolimus (CYPHER and TAXUS respectively) stents than was then currently included in the product labelling (US Food \& Drug Administration update available at

http://www.fda.gov/cdrh/news/010407.html last accessed
July 2013). The same update admitted that the optimal duration of antiplatelet therapy, specifically clopidogrel, was unknown. The update quoted the then current ACC/AHA/SCAI PCI Practice guidelines, which recommended that patients receive aspirin indefinitely plus a minimum of 3 months clopidogrel for sirolimus (CYPHER) DES patients and 6 months clopidogrel for paclitaxel (TAXUS) DES patients [37]. Meanwhile, further advances with second generation DES such as everolimus-eluting stents (EES) or zotarolimus-eluting stents (ZES) and third generation DES with biodegradable polymers and abluminal coating such as biolimus-eluting stent (BES) have largely replaced first generation DES. These new stents offer improved stent deliverability with equal or superior anti-proliferative efficacy and a consistently lower rate of late or very late stent thrombosis $[38,39]$.

\section{EMERGING PERIOPERATIVE RISK}

Unfortunately the population that required angioplasty and stent insertion was middle-aged males and elderly males and females [40]. This was exactly the population of patients that often required surgery for other urgent and elective conditions and the treatment of these patients with clopidogrel at the time of surgery caused considerable perioperative bleeding complications $[1,3,8,41$, 42]. However the cessation of clopidogrel at the time of operation also increased the risk of in-stent thrombosis with a significant risk of acute myocardial infarction and death $[1,3,6,42]$. The reported high mortality rates from in-stent thrombosis were not experienced by the Geelong group who reported no mortalities in their three patients with in-stent thrombosis [6,8,9,42-47].

Some authors have reported a difference in the residual effect of the "first generation" Paclitaxel and Sirolimus DES [24,25,44]. The advice to surgeons and perioperative physicians can therefore be modified to reduce the time when clopidogrel is required following Sirolimus DES insertion [48-50]. However the requirement for clopidogrel or bridging treatment at the time of surgery may still need to be considered following first generation DES insertion [51]. In-stent thrombosis has been reported up to 7 years following first generation DES insertion [52].

\section{THE "BRIDGING" SOLUTION}

The solution was developed by interventional cardiologists, perioperative physicians and pharmacists together. This was a bridging therapy that recognised the findings of the PRISM study and the pharmacokinetics of the oral P2Y12 inhibitor clopidogrel and the intravenous glycoprotein IIb/IIIa inhibitor tirofiban [46,47,53, 54]. In Geelong we pioneered the introduction of this 
novel "bridging therapy", which appeared to avoid the dual risks of major haemorrhage and in-stent thrombosis $[46,47]$. The risk of major haemorrhage was avoided by replacing the long acting P2Y12 inhibitor, clopidogrel with a shorter acting intravenous glycoprotein IIb/IIIa inhibitor tirofiban and the anticoagulant heparin in line with the PRISM study [33,55]. The risk of in-stent thrombosis was avoided by strict timing of the drug regime to minimise the time the patient was at risk of thrombosis [46,47]. Using this bridging therapy the Geelong group was able to demonstrate prevention of thrombotic and bleeding complications in about 20 patients [46]. Subsequent authors have endorsed the same principle and achieved similar results without the addition of heparin but the principle of "bridging therapy" for these patients remains sound [53,54]. In Milan Savonnito's group had collected data on an alternative bridging therapy using tirofiban alone with no in-stent thrombosis, although bleeding problems were reported in this group of patients [53]. We have calculated that with the $71 \mathrm{pa}-$ tients reported in the literature and our own unreported experience there have now been $>100$ patients treated with tirofiban "bridging therapy" with no in-stent thrombosis and minor bleeding complications [47,53,54]. Compared to the earlier "disastrous" data reported for urgent or emergency surgery on patients with DES receiving clopidogrel the bridging therapy showed considerable benefit.

\section{THE "BIOCOMPATIBLE" STENT}

The interventional cardiology device industry was also evolving with new ideas and a new device trialled that could replace the old antimitotic DES [56]. This was a bare-metal coronary stent that contained a monoclonal antibody that actually attracted endothelial cells to colonise the device and therefore significantly reduced the time that the thrombus generating bare metal was exposed to the platelets and blood clotting factors $[57,58]$. The newer monoclonal antibody containing BMS have the same intent as the earlier stents. These BMS, unlike their precursors, need a much shorter time of treatment with the potent long acting P2Y12 inhibitor clopidogrel with only 10 days of treatment required [59]. These "biocompatible" stents have further improved the safety envelope, and again modified the guidelines for aspirin, antiplatelet drugs and anticoagulation in the perioperative period.

The upshot of the evolution in the practice of interventional cardiologists and the interventional device manufacturers is that there are now several devices in use with different recommendations for their peri-procedural and subsequent perioperative management [15] (See Table 1).
Table 1. Summary of guidelines for perioperative management after stent insertion.

\begin{tabular}{cll}
\hline Stent Type & \multicolumn{1}{c}{$\begin{array}{c}\text { Clopidogrel } \\
\text { Treatment }\end{array}$} & $\begin{array}{c}\text { Perioperative } \\
\text { management }\end{array}$ \\
\hline Bare-metal stent BM & $4-6$ weeks & $\begin{array}{l}\text { Tirofiban/Heparin } \\
\text { "bridging” if on } \\
\text { clopidogrel }\end{array}$ \\
$\begin{array}{c}\text { CYPHER sirolimus } \\
\text { DES }\end{array}$ & 12 months & $\begin{array}{l}\text { Tirofiban/Heparin } \\
\text { "bridging” if on } \\
\text { clopidogrel }\end{array}$ \\
$\begin{array}{c}\text { TAXUS paclitaxel } \\
\text { DES }\end{array}$ & 12 months & No bridging required \\
$\begin{array}{c}\text { GENOUS }{ }^{\mathrm{TM}} \text { R Stent } \\
10 \text { days clopidogrel }\end{array}$ & $\begin{array}{l}\text { Tirofiban/Heparin } \\
\text { "bridging” if on } \\
\text { clopidogrel }\end{array}$ \\
$\begin{array}{c}\text { Second generation } \\
\text { DES }\end{array}$ & $\begin{array}{l}12 \text { months (if } \\
\text { implanted for ACS) }\end{array}$ \\
\hline
\end{tabular}

In summary the following guidelines are now current for stents deployed in the coronary circulation.

1) Bare metal stents

These devices will require 4 - 6 weeks of dual antiplatelet therapy after insertion followed by aspirin alone. If surgery is required in the first 4 weeks after insertion bridging therapy with tirofiban should be considered if aspirin cannot be maintained. Heparin is optional but the safety profile for bridging with tirofiban is good $[47,53$, 54]. If surgery is required more than 4 weeks after insertion of a BMS clopidogrel can be ceased and aspirin should be continued at the time of surgery [60].

2) First generation DES: Sirolimus or Paclitaxel DES

The current data and available reports suggest an increased risk of perioperative in-stent thrombosis associated with DES in patients undergoing surgery within 12 months after a percutaneous coronary intervention (PCI) [60]. Furthermore, sudden withdrawal of antiplatelet therapy may trigger a rebound effect and temporarily increase the risk of in-stent thrombosis [61,62]. Therefore, prevention of such potentially high risk coronary events is crucial. Previously reported data have suggested that the rate of major adverse cardiovascular events with DES were higher in early surgery compared with late surgery ( $>12$ months) with no significant difference between either sirolimus eluting stents or paclitaxel eluting stents. Clopidogrel and aspirin should be continued for 12 months after insertion [63]. If surgery is required during this interval bridging therapy with tirofiban and optional heparin should be used to prevent in-stent thrombosis and reduce the risk of catastrophic haemorrhage [47,53,54]. Aspirin should be continued for life as discontinuation, even more than 1 year after insertion, may lead to stent thrombosis [60].

3) Biocompatible stent (Genous ${ }^{\mathrm{TM}}$ bio-engineered Rstent $^{\mathrm{TM}}$ )

The Genous ${ }^{\mathrm{TM}}$ bio-engineered R-stent ${ }^{\mathrm{TM}}$ would appear to be the safest stents of all with respect to surgical and anaesthetic interventions, with such a short duration of 
clopidogrel treatment that the likelihood of complications at the time of surgery is minimal [59]. After stenting patients receive clopidogrel for 10 days and then lifelong aspirin treatment.

\section{4) Second generation DES (EES \& ZES)}

These second generation stents are the Everolimus eluting stent (EES) and the Zotarolimus eluting stent (ZES). The reports from several recently published studies have shown newer generation DES have beneficial efficacy and safety despite a relatively short duration of dual antiplatelet therapy of 3 to 6 months. However some patient-related factors and device-related criteria that determine safety and allow early dual antiplatelet therapy withdrawal, or interruption e.g. for urgent surgery, still have to be determined [64,65]. It remains unclear whether there is a "safe" time threshold with the $2^{\text {nd }}$ generation DES, for clopidogrel discontinuation, after which event rates are negligible.

\section{CONCLUSIONS}

The evolution of stent insertion following coronary angioplasty has been complex with four different types of stent deployed in the coronary circulation after the procedure. We have described the recommended use of antiplatelet agents and management of patients who have had coronary stents inserted in the setting of elective or emergency surgery.

Information about the properties of each stent and the details of the antiplatelet therapy inform the process of management for perioperative physicians and anaesthetists at the time of urgent or elective surgery in these patients. Different devices require different management plans at different times after insertion. By summarising this information, we hope to facilitate the optimal management of these patients.

\section{REFERENCES}

[1] Wilson, S.H., Fasseas, P., Oxford, J.L., Lennon, R.J., Horlocker, T., Charnoff, N.E., Melby, S. and Berger, P.B. (2003) Clinical outcomes of patients undergoing noncardiac surgery in the two months following coronary stenting. Journal of the American College of Cardiology, 42, 234-240.

http://dx.doi.org/10.1016/S0735-1097(03)00622-3

[2] Eisenberg, M.J. (2004) Drug-eluting stents: Some bare facts. Lancet, 364, 1466-1467. http://dx.doi.org/10.1016/S0140-6736(04)17287-5

[3] Spahn, D.R., Howell, S.J., Delabays, A. and Chassot, P.-G. (2006) Coronary stents and perioperative anti-platelet regimen: Dilemma of bleeding and stent thrombosis. British Journal of Anaesthesia, 96, 675-677. http://dx.doi.org/10.1093/bja/ael098

[4] Tsimikas, S. (2006) Drug-eluting stents and late adverse clinical outcomes lessons learned, lessons awaited. Jour- nal of the American College of Cardiology, 47, 2112 2115. http://dx.doi.org/10.1016/j.jacc.2006.03.019

[5] Lee, C.H., Lim, J., Low, A., Tan, H.C. and Lim, Y.T. (2006) Late angiographic stent thrombosis of polymer based paclitaxel eluting stent. Heart, 92, 551-553. http://dx.doi.org/10.1136/hrt.2005.073619

[6] Nasser, M., Kapelovich, M. and Markiewicz, W. (2005) Late thrombosis of sirolumus-eluting stents following noncardiac surgery. Catheterization and Cardiovascular Interventions, 65, 516-519.

http://dx.doi.org/10.1002/ccd.20391

[7] McFadden, E.P., Stabile, E., Regar, E., Cheneau, E., Ong, A.T.L., Kinnaird, T., Suddath, W.O., Weissman, N.J., Torguson, R., Kent, K.M., et al. (2004) Late thrombosis in drug-eluting coronary stents after discontinuation of antiplatelet therapy. Lancet, 364, 1519-1521. http://dx.doi.org/10.1016/S0140-6736(04)17275-9

[8] Serruys, P.W. and Daemen, J. (2007) Late stent thrombosis: A nuisance in both bare metal and drug-eluting stents. Circulation, 115, 1433-1439. http://dx.doi.org/10.1161/CIRCULATIONAHA.106.6668 $\underline{26}$

[9] Daemen, J., Wenaweser, P., Tsuchida, K., Abrecht, L., Vaina, S., Morger, C., Kukreja, N., Juni, P., Sianos, G., Hellige, G., et al. (2007) Early and late coronary stent thrombosis of sirolimus-eluting and paclitaxel-eluting stents in routine clinical practice: Data from a large twoinstitutional cohort study. Lancet, 369, 667-678. http://dx.doi.org/10.1016/S0140-6736(07)60314-6

[10] Urban, P. and De Benedetti, E. (2007) Thrombosis: The last frontier of coronary stenting? Lancet, 369, 619-621. http://dx.doi.org/10.1016/S0140-6736(07)60289-X

[11] Ong, A.T., McFadden, E.P., Regar, E., de Jaegere, P.P., van Domburg, R.T. and Serruys, P.W. (2005) Late angiographic stent thrombosis (LAST) events with drug-eluting stents. Journal of the American College of Cardiology, 45, 2088-2092. http://dx.doi.org/10.1016/j.jacc.2005.02.086

[12] Joner, M., Finn, A.V., Farb, A., Mont, E.K., Kolodgie, F.D., Ladich, E., Kutys, R., Skorija, K., Gold, H.K. and Virmani, R. (2006) Pathology of drug-eluting stents in humans: Delayed healing and late thrombotic risk. Journal of the American College of Cardiology, 48, 193-202. http://dx.doi.org/10.1016/j.jacc.2006.03.042

[13] Virmani, R., Guagliumi, G., Farb, A., Musumeci, G., Grieco, N., Motta, T., Mihalcsik, L., Tespili, M., Valsecchi, O. and Kolodgie, F.D. (2004) Localized hypersensitivity and late coronary thrombosis secondary to a sirolimus-eluting stent. Circulation, 109, 701-705. http://dx.doi.org/10.1161/01.CIR.0000116202.41966.D4

[14] Sharma, A.K., Ajani, A.E., Hamwi, S.M., Maniar, P., Lakhani, S.V., Waksman, R. and Lindsay, J. (2004) Major noncardiac surgery following coronary stenting: When is it safe to operate? Catheterization and Cardiovascular Interventions, 63, 141-145. http://dx.doi.org/10.1002/ccd.20124

[15] Australia \& New Zealand Cardiac Society, Guidelines Committee (2010) Guidelines for the management of antiplatelet therapy in patients with coronary stents un- 
dergoing non-cardiac surgery. Heart, Lung \& Circulation, 19, 2-10. http://dx.doi.org/10.1016/j.hlc.2009.10.008

[16] Howard-Alpe, G.M., de Bono, J., Hudsmith, L., Orr, W.P., Foex, P. and Sear, J.W. (2007) Coronary artery stents and non-cardiac surgery. British Journal of Anaesthesia, 98, 560-574. http://dx.doi.org/10.1093/bja/aem089

[17] Harper, R.W. (2007) Drug-eluting coronary stents-A note of caution. Medical Journal of Australia, 186, 253255.

[18] Dupuis, J.-Y. and Labinaz, M. (2005) Noncardiac surgery in patients with coronary artery stent: What should the anesthesiologist know? Canadian Journal of Anesthesia, 52, 356-361. http://dx.doi.org/10.1007/BF03016276

[19] Patterson, L., Hunter, D. and Mann, A. (2005) Appropriate waiting time for noncardiac surgery following coronary stent insertion: Views of Canadian anesthesiologists. Canadian Journal of Anesthesia, 52, 440-441. http://dx.doi.org/10.1007/BF03016295

[20] Iakovou, I., Schmidt, T., Bonizzoni, E., Ge, L., Sangiorgi, G.M., Stankovic, G., Airoldi, F., Cheiffo, A., Montorfarno, M., Carlino, M., et al. (2005) Incidence, predictors, and outcome of thrombosis after successful implantation of drugeluting stents. JAMA, 293, 2126-2130.

http://dx.doi.org/10.1001/jama.293.17.2126

[21] Brilakis, E.S., Banerjee, S. and Berger, P.B. (2007) Perioperative management of patients with coronary stents. Journal of the American College of Cardiology, 49, 21452150. http://dx.doi.org/10.1016/j.jacc.2007.02.046

[22] Fox, K.A., Mehta, S.R., Peters, R., Zhao, F., Lakkis, N., Gersh, B.J. and Yusuf, S. (2004) Benefits and risks of the combination of clopidogrel and aspirin in patients undergoing surgical revascularization for non-ST-elevation acute coronary syndrome: The Clopidogrel in Unstable angina to prevent Recurrent ischemic Events (CURE) Trial. Circulation, 110, 1202-1208.

http://dx.doi.org/10.1161/01.CIR.0000140675.85342.1B

[23] Kotani, J., Awata, M., Nanto, S., Uematsu, M., Oshima, F., Minamiguchi, H., Mintz, G.S. and Nagata, S. (2006) Incomplete neointimal coverage of sirolimus-eluting stents: Angioscopic findings. Journal of the American College of Cardiology, 47, 2108-2111. http://dx.doi.org/10.1016/j.jacc.2005.11.092

[24] Spaulding, C., Henry, P., Teiger, E., Beatt, K., Bramucci, E., Carrie, D., Slama, M.S., Merkely, B., Erglis, A., Margheri, M., et al. (2006) Sirolimus-eluting versus uncoated stents in acute myocardial Infarction. The New England Journal of Medicine, 355, 1093-1104. http://dx.doi.org/10.1056/NEJMoa062006

[25] Wessely, R., Schomig, A. and Kastrati, A. (2006) Sirolimus and Paclitaxel on polymer-based drug-eluting stents: Similar but different. Journal of the American College of Cardiology, 47, 708-714. http://dx.doi.org/10.1016/j.jacc.2005.09.047

[26] Kuchulakanti, P.K., Chu, W.W., Torguson, R., Ohlmann, P., Rha, S.W., Clavijo, L.C., Kim, S.W., Bui, A., Gevorkian, N., Xue, Z., et al. (2006) Correlates and long-term outcomes of angiographically proven stent thrombosis with sirolimus- and paclitaxel-eluting stents. Circulation, 113, 1108-1113.
http://dx.doi.org/10.1161/CIRCULATIONAHA.105.6001 $\underline{55}$

[27] Daemen, J., Garcia-Garcia, H.M., Kukreja, N., Imani, F., de Jaegere, P.P., Sianos, G., van Domburg, R.T. and Serruys, P.W. (2007) The long-term value of sirolimusand paclitaxel-eluting stents over bare metal stents in patients with diabetes mellitus. European Heart Journal, 28, 26-32. http://dx.doi.org/10.1093/eurhearti/ehl412

[28] Gershlick, A.H. (2005) Is there any place for oral antirestenotic treatment in the era of drug eluting stents? Heart, 91, 1377-1379.

http://dx.doi.org/10.1136/hrt.2005.060954

[29] Camenzind, E. (2006) Treatment of in-stent restenosis -Back to the future? The New England Journal of Medicine, 355, 2149-2151. http://dx.doi.org/10.1056/NEJMe068215

[30] Karthikeyan, G. and Bhargava, B. (2004) Prevention of restenosis after coronary angioplasty. Current Opinion in Cardiology, 19, 500-509.

http://dx.doi.org/10.1097/01.hco.0000133658.77024.59

[31] Heeschen, C., Hamm, C.W., Goldmann, B., Deu, A., Langenbrink, L. and White, H.D. (1999) Troponin concentrations for stratification of patients with acute coronary syndromes in relation to therapeutic efficacy of tirofiban. Lancet, 354, 1757-1762. http://dx.doi.org/10.1016/S0140-6736(99)10285-X

[32] Zidar, J.P. (1998) Low-molecular heparins in coronary stenting (the Entices trial). ENoxaparin and TIClodipine after Elective Stenting. American Journal of Cardiology, 82, 29L-32L. http://dx.doi.org/10.1016/S0002-9149(98)00110-6

[33] Investigators, T.P.-P. (1998) Inhibition of the platelet glycoprotein IIb/IIIa teceptor with tirofiban in unstable angina and non-Q-wave myocardial infarction. The New England Journal of Medicine, 338, 1488-1497. http://dx.doi.org/10.1056/NEJM199805213382102

[34] Kristensen, S.D., Wurtz, M., Grove, E.L., De Caterina, R., Hubert, K., Moliterno, D.J. and Neumann, F.-J. (2012) Contemporary use of glycoprotein IIb/IIIa inhibitors. Thrombosis and Haemostasis, 107, 215-224. http://dx.doi.org/10.1160/TH11-07-0468

[35] Chassot, P.-G., Delabays, A. and Spahn, D.R. (2007) Perioperative antiplatelet therapy: The case for continuing therapy in patients at risk of myocardial infarction. British Journal of Anaesthesia, 99, 316-328. http://dx.doi.org/10.1093/bja/aem209

[36] Nuttall, G.A., Brown, M.J., Stombaugh, J.W., Michon, P.B., Hathaway, M.F., Lindeen, K.C., Hanson, A.C., Schroeder, D.R., Oliver, W.C., Holmes, D.R., et al. (2008) Time and cardiac risk of surgery after bare-metal stent percutaneous coronary intervention. Anesthesiology, 109, 588-595 http://dx.doi.org/10.1097/ALN.0b013e318186ddf8

[37] Bolsin, S.N., Broad, L., Conroy, M., Black, S., Orford, N. and Birdsey, G. (2007) Successful management of patients with a drug-eluting coronary stent presenting for elective surgery. British Journal of Anaesthesia, 98, 841842. http://dx.doi.org/10.1093/bja/aem110

[38] Raber, L., Magro, M., Stefanini, G.G., Kalesan, B., Dom- 
burg, van R.T., Onuma, Y., Wenaweser, P., Daemen, J., Meier, B., Juni, P., et al. (2012) Very late coronary stent thrombosis of a newer-generation everolimus-eluting stent compared with early-generation drug-eluting stents: A prospective cohort study. Circulation, 125, 1110-1121. http://dx.doi.org/10.1161/CIRCULATIONAHA.111.0585 60

[39] Stefanini, G.G., Byrne, R.A., Serruys, P.W., Waha, de A., Meier, B., Massberg, S., Jani, P., Schamig, A., Windecker, S. and Kastrati, A. (2012) Biodegradable polymer drugeluting stents reduce the risk of stent thrombosis at 4 years in patients undergoing percutaneous coronary intervention: A pooled analysis of individual patient data from the ISAR-TEST 3, ISAR-TEST 4, and LEADERS randomized trials. European Heart Journal, 33, 1214-1222. http://dx.doi.org/10.1093/eurheartj/ehs086

[40] Dalal, A.R., D’Souza, S. and Shulman, M. (2006) Brief review: Coronary drug-eluting stents and anesthesia. Canadian Journal of Anesthesia, 53, 1230-1243. http://dx.doi.org/10.1007/BF03021585

[41] Shuchman, M. (2007) Debating the risks of drug-eluting stents. The New England Journal of Medicine, 356, 325328. http://dx.doi.org/10.1056/NEJMp068300

[42] Kaluza, G.L., Joseph, J., Lee, J.R., Raizner, M.E. and Raizner, A.E. (2000) Catastrophic outcomes of noncardiac surgery soon after coronary stenting. Journal of the American College of Cardiology, 35, 1288-1294. http://dx.doi.org/10.1016/S0735-1097(00)00521-0

[43] Vicenzi, M.N., Meislitzer, T., Heitzinger, B., Halaj, M., Fleisher, L.A. and Metzler, H. (2006) Coronary artery stenting and non-cardiac surgery-A prospective outcome study. British Journal of Anaesthesia, 96, 686-693. http://dx.doi.org/10.1093/bja/ael083

[44] Liistro, F. and Colombo, A. (2001) Late acute thrombosis after paclitaxel eluting stent implantation. Heart, 86, 262264. http://dx.doi.org/10.1136/heart.86.3.262

[45] Spaulding, C., Daemen, J., Boersma, E., Cutlip, D.E. and Serruys, P.W. (2007) A pooled analysis of data comparing sirolimus-eluting stents with bare-metal stents. The New England Journal of Medicine, 356, 989-997. http://dx.doi.org/10.1056/NEJMoa066633

[46] Conroy, M., Bolsin, S.N., Black, S.A. and Orford, N. (2007) Perioperative complications in patients with drugeluting stents: A three-year audit at Geelong Hospital. Anaesthesia and Intensive Care, 35, 939-944.

[47] Broad, L., Lee, T., Conroy, M., Bolsin, S., Orford, N., Black, A. and Birdsey, G. (2007) Successful management of patients with a drug-eluting coronary stent presenting for elective, non-cardiac surgery. British Journal of Anaesthesia, 98, 19-22. http://dx.doi.org/10.1093/bja/ael318

[48] Barthwal, R. and Herman, B.A. (2008) Very late stent thrombosis after discontinuation of clopidogrel therapy. Medical Journal of Australia, 189, 229-230.

[49] Godet, G., Le Manach, Y., Lesache, F., Perbet, S. and Coriat, P. (2008) Drug-eluting stent thrombosis in patients undergoing non-cardiac surgery: Is it always a problem? British Journal of Anaesthesia, 100, 472-477. http://dx.doi.org/10.1093/bja/aen033

[50] Barash, P. and Akhtar, S. (2010) Coronary stents: Factors contributing to perioperative major adverse cardiovascular events. British Journal of Anaesthesia, 105, i3-i15. http://dx.doi.org/10.1093/bja/aeq318

[51] Park, D.W., Park, S.W., Park, K.H., Lee, B.K., Kim, Y.H., Lee, C.W., Hong, M.K., Kim, J.J. and Park, S.J. (2006) Frequency of and risk factors for stent thrombosis after drug-eluting stent implantation during long-term followup. American Journal of Cardiology, 98, 352-356. http://dx.doi.org/10.1016/j.amjcard.2006.02.039

[52] Taylor-Sutton, J.E. (2011) Very late stent thrombosis approximately 7 years after deployment and one week cessation of dual antiplatelet therapy. Journal of Invasive Cardiology, 23, E273-E276.

[53] Savonitto, S., D’Urbano, M., Caracciolo, M., Barlocco, F., Mariani, G., Nichelatti, M., Klugmann, S. and De Servi, S. (2010) Urgent surgery in patients with a recently implanted coronary drug-eluting stent: A phase II study of "bridging" antiplatelet therapy with tirofiban during temporary withdrawal of clopidogrel. British Journal of Anaesthesia, 104, 285-291. http://dx.doi.org/10.1093/bja/aep373

[54] Marcos, E.G., Da Fonseca, A.C. and Hofma, S.H. (2011) Bridging therapy for early surgery in patients on dual antiplatelet therapy after drug-eluting stent implantation. Netherlands Heart Journal, 19, 412-417. http://dx.doi.org/10.1007/s12471-011-0197-y

[55] Weber, A.A., Braun, M., Hohfeld, T., Schwippert, B., Tschöpe, D. and Schrör, K. (2001) Recovery of platelet function after discontinuation of clopidogrel treatment in healthy volunteers. British Journal of Clinical Pharmacology, 52, 333-336. http://dx.doi.org/10.1046/j.0306-5251.2001.01453.x

[56] Duckers, H.J., Silber, S., Winter, de R., Heijer, den P., Rensing, B., Rau, M., Mudra, H., Benit, E., Verheye, S., Wijns, W., et al. (2007) Circulating endothelial progenitor cells predict angiographic and intravascular ultrasound outcome following percutaneous coronary interventions in the HEALING-II trial: Evaluation of an endothelial progenitor cell capturing stent. EuroIntervention, 3, 67-75. http://dx.doi.org/10.4244/EIJV3I3A64

[57] Aoki, J., Serruys, P.W., Beusekom, van H., Ong, A.T.L., McFadden, E.P., Sianos, G., Giessen, van der W.J., Regar, E., Feyter, de P.J., Davis, H.R., et al. (2005) Endothelial progenitor cell capture by stents coated with antibody against CD34: The HEALING-FIM (Healthy Endothelial Accelerated Lining Inhibits Neointimal Growth-First in Man) Registry. Journal of the American College of Cardiology, 45, 1574-1579. http://dx.doi.org/10.1016/j.jacc.2005.01.048

[58] Duckers, H.J., Soullié, T., Heijer, den P., Rensing, B., Winter, de R.J., Rau, M., Mudra, H., Silber, S., Benit, E., Verheye, S., et al. (2007) Accelerated vascular repair following percutaneous coronary intervention by capture of endothelial progenitor cells promotes regression of neointimal growth at long term follow-up: Final results of the Healing II trial using an endothelial progenitor cell capturing stent (Genous R stent). EuroIntervention, 3, 350358. http://dx.doi.org/10.4244/EIJV3I3A64

[59] Sangiorgi, G., Morice, M.-C., Bramucci, E., Ferlini, M., Grinfeld, L., Petronio, A.S., Pierli, C., Iadanza, A., Biondi-Zoccai, G. and Colombo, A. (2011) Evaluating the 
safety of very short-term (10 days) dual antiplatelet therapy after Genous bio-engineered $\mathrm{R}$ stent implantation: The multicentre pilot GENOUS trial. EuroIntervention, 7, 813-819. http://dx.doi.org/10.4244/EIJV7I7A128

[60] Grines, C.L., Bonow, R.O., Casey, D.E., Gardner, T.J., Lockhart, P.B., Moliterno, D.J., O’Gara, P. and Whitlow, P. (2007) Prevention of premature discontinuation of dual antiplatelet therapy in patients with coronary artery stents: A science advisory from the American Heart Association, American College of Cardiology, Society for Cardiovascular Angiography and Interventions, American College of Surgeons, and American Dental Association, with representation from the American College of Physicians. Circulation, 115, 813-818.

http://dx.doi.org/10.1161/CIRCULATIONAHA.106.1809 $\underline{44}$

[61] Collet, J.P., Montalescot, G., Blanchet, B., Tanguy, M.L., Golmard, J.L., Choussat, R., Beygui, F., Payot, L., Vignolles, N., Metzger, J.P., et al. (2004) Impact of prior use or recent withdrawal of oral antiplatelet agents on acute coronary syndromes. Circulation, 110, 2361-2367. http://dx.doi.org/10.1161/01.CIR.0000145171.89690.B4

[62] Ferrari, E., Benhamou, M., Cerboni, P. and Marcel, B. (2005) Coronary syndromes following aspirin withdrawal. Journal of the American College of Cardiology, 45, 456459. http://dx.doi.org/10.1016/j.jacc.2004.11.041
[63] Levine, G.N., Bates, E.R., Blankenship, J.C., Bailey, S.R., Bittl, J.A., Cercek, B., Chambers, C.E., Ellis, S.G., Guyton, R.A., Hollenberg, S.M., et al. (2011) ACCF/AHA/ SCAI guideline for percutaneous coronary intervention: A report of the American College of Cardiology Foundation/American Heart Association Task Force on Practice Guidelines and the Society for Cardiovascular Angiography and Interventions. Circulation, 124, e574-e651. http://dx.doi.org/10.1161/CIR.0b013e31823ba622

[64] Ferreira-Gonzalez, I., Marsal, J.R., Ribera, A., Permanyer-Miralda, G., Garcia-Del, Blanco B., Marta, G., Cascant, P., Masotti-Centol, M., Carrillo, X., Mauri, J., et al. (2012) Double antiplatelet therapy after drug-eluting stent implantation: Risk associated with discontinuation within the first year. Journal of the American College of Cardiology, 60, 1333-1339. http://dx.doi.org/10.1016/j.jacc.2012.04.057

[65] Kim, B.-K., Hong, M.-K., Shin, D.-H., Nam, C.-M., Kim, J.-S., Ko, Y.-G., Choi, D., Kang, T.-S., Park, B.-E., Kang, W.-C., et al. (2012) A new strategy for discontinuation of dual antiplatelet therapy: The RESET Trial (REal Safety and Efficacy of 3-month dual antiplatelet Therapy following Endeavor zotarolimus-eluting stent implantation). Journal of the American College of Cardiology, 60, 13401348. http://dx.doi.org/10.1016/j.jacc.2012.06.043 